\title{
Probabilistic model for understand presence of Temnocephala chilensis (Moquin-Tandom 1846) (Platyhelminthes: Temnocephalidae) on adults of a population of Parastacus pugnax (Poeppig 1835) (Decapoda: Parastacidae) in southern Chile
}

\begin{abstract}
Modelo probabilistico para comprender la presencia de Temnocephala chilensis (Moquin-Tandom 1846) (Platyhelminthes: Temnocephalidae) en una población adulta de Parastacus pugnax (Poeppig 1835) (Decapoda: Parastacidae) en el sur de Chile
\end{abstract}

\author{
Patricio De los Rios-Escalante ${ }^{12,1^{*}}$, Italo Salgado ${ }^{3}$, Carlos Rauque ${ }^{4} \&$ Noemit Gonzalez ${ }^{3}$ \\ ${ }^{1}$ Laboratorio de Ecología Aplicada y Biodiversidad, Escuela de Ciencias Ambientales, Facultad de Recursos Naturales, Uni- \\ versidad Católica de Temuco, Casilla 15-D, Temuco, Chile.E-mail prios@uct.cl \\ ${ }^{2}$ Núcleo de Estudios Ambientales UCTemuco. \\ ${ }^{3}$ Escuela de Acuicultura, Facultad de Recursos Naturales, Universidad Católica de Temuco, Casilla 15-D, Temuco, Chile. \\ ${ }^{4}$ Laboratorio de Parasitología INIBIOMA (CONICET-Universidad Nacional del Comahue), Avda. Quintral 1250, 8400 San Car- \\ los de Bariloche, Río Negro, Argentina.
}

\begin{abstract}
The literature reported ectocommensals associated to Parastacus pugnax (Poeppig, 1835), but there are not ecological studies about abundance of these on P. pugnax. The aim of the present study was to analyze the abundances of ectocommensal Temnocephala chilensis (Moquin-Tandom, 1846), on P.pugnax. It had not correlation between T. chilensis number with total length and total weight of $P$. pugnax. T. chilensis has an associated spatial distribution and negative binomial distribution. Ecological and evolutive topics were discussed.
\end{abstract}

KeYwords: Parastacus pugnax, Temnocephala chilensis, negative binomial distribution, ectocommensals.

\section{RESUMEN}

La literatura reporta la presencia de ectocomensales asociados a Parastacus pugnax (Poeppig, 1835), pero no hay estudios ecológicos sobre la abundancia de estos sobre P. pugnax. El objetivo del presente estudio fue analizar la presencia de Temnocephala chilensis (Moquin-Tandom 1846), en P.pugnax. No hubo correlación significativa entre el número de individuos de T. chilensis con el largo total y el peso total. T. chilensistiene un patrón de distribución espacial agregada y distribución binomial negativa. Se discuten tópicos ecológicos y evolutivos.

Palabras Clave: Parastacus pugnax, Temnocephala chilensis, distribución binomial negativa, ectocomensal.

The Chilean inland water malacostracan have been poorlystudied in many biological topics, including their species interactions (Rudolph 2002, 2010, 2013). In Chile there are six species of crayfish of the family Parastacidae, which live in littoral zones in rivers, swamps, or flooded plains in Central and Southern Chile (Rudolph 2010). For the $P$. pugnax there are studies about commensals such as Temnocephala chilensis (Moquin-Tandom 1846) (Plathyelminthes; Temnocephalida), Stratiodrilus pugnaxi Vila and Bahamonde 1985 (Polichaeta, Histriobdellidae),
Operculigera assymetrica (Clamp 1991), O. insolita (Clamp 1991), O. parastaci (Clamp 1991), O. seticola (Clamp 1991), O. striata (Clamp 1991), Lagenophys andops (Jankoswki 1986), L. antichtos (Clamp 1991)(Ciliophora, Peritricha, Lagenophryidae)(Rudolph 2013). Nevertheless there are not quantitative studies about the presence of these species on their hosts.

Specimens of P.pugnax were collected from Ranquilco valley, a flooded plain close to Temuco (38 $42^{\prime}$ 'S; $\left.73^{\circ} 04^{\prime} \mathrm{W}\right)$, 
Chile. Fresh specimens were observed under microscope and for each one wasextracted $T$. chilensis specimens that were fixed in absolute ethanol. Each crustacean was weighted and total length from tip of the telson to the top of rostrum was measured with manual caliperin laboratory. Specimens were collected in two different times during August 2011.

The obtained data were analyzed in two steps; in a first step, it was determined the presence of potential association between abundance of $T$. chilensis individuals by total length and total weight using a correlation analysis. Posteriorly, a non randomness test was applied considering the variance and mean ratio of $T$. chilensis individuals by $P$. pugnax individuals with the aim to determine if $T$. chilensis individuals are distributed random, or aggregate (Zar 1999).

On the basis of these last results, it was applied a second probability test to determine if the $T$. chilensis individuals had Poisson, negative binomial or positive binomial distribution (Fernandez et al. 2003). All statistical analysis was applied using the software Xlstat 5.0.

The total length of $P$. pugnax adults varied between 32 to $49 \mathrm{~mm}$ whereas total weight varied between 2.1 and $36.8 \mathrm{~g}$ and abundance of $T$. chilensis individuals varied from 0 to 20 (Table 1). The results revealed the absence of significant correlation between abundance of $T$. chilensis individuals and total length and total weight (Fig. 1). The results of non randomness test revealed for the two sample groups the existence of an aggregated pattern (Table 1), and this pattern was adjusted to a negative binomial distribution (Table 1, Fig. 2).
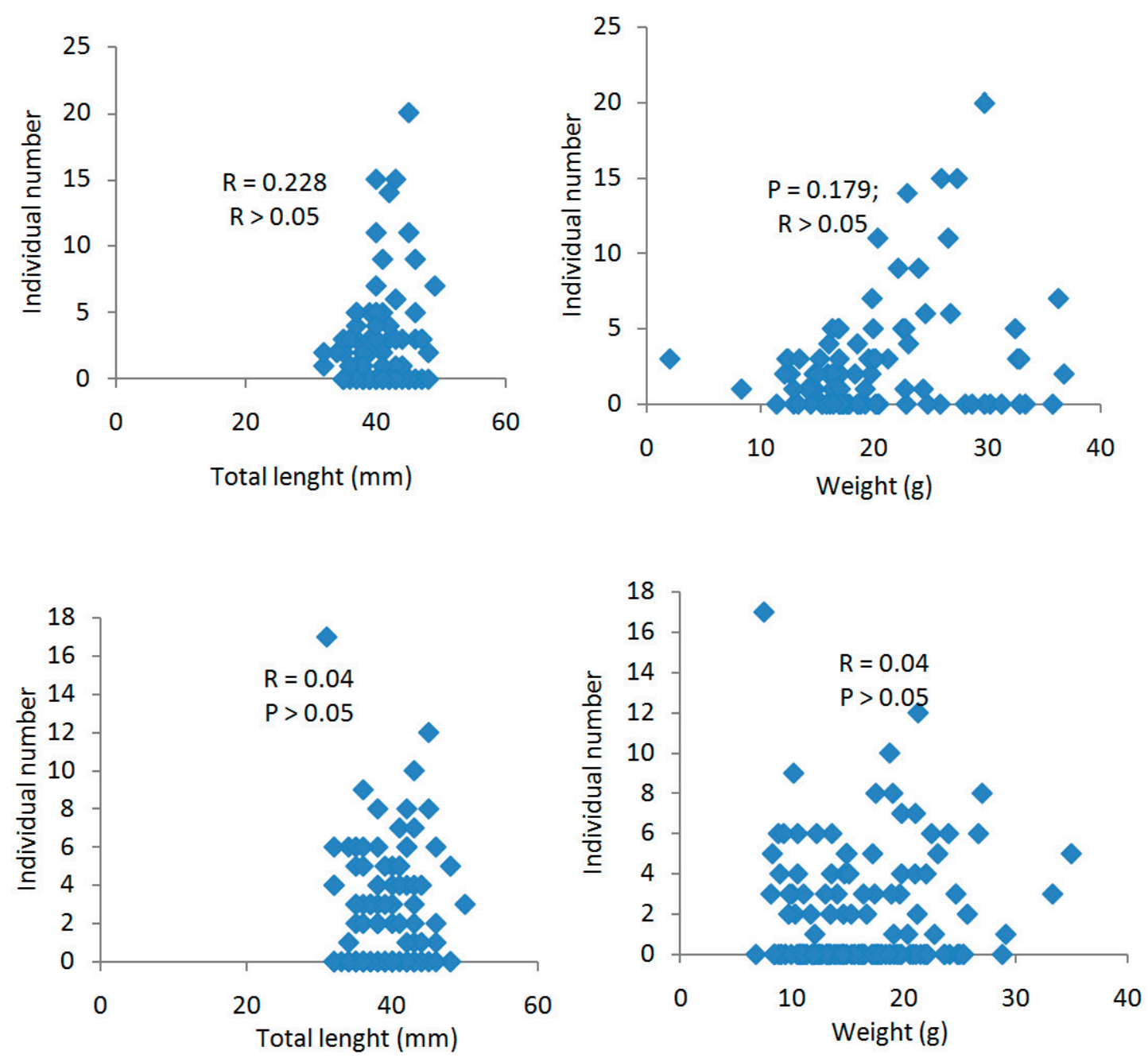

FIGURE 1. Correlation analysis between $T$. chilensis individuals with total length and total weight in two P. pugnax sampled groups (first group up, $01^{\text {th }}$ August 2012, second group low, 30 ${ }^{\text {th }}$ August 2012).

Figura. 1. Análisis de correlación entre individuos de T. chilensis con el largo total y peso total en dos grupos muestreados de P.pugnax (primer grupo 01 de agosto de 2012, segundo grupo 30 de agosto de 2012). 
Probabilistic model for understand presence of T. chilensis: P. DE Los Ríos ET AL.

TABLE 1. Data of P. pugnax and T. chilensis, and results of variance /mean ratio of $T$. chilensis sampled in the present study.

TABLA 1.Datos de P. pugnax y T. chilensis y resultados de la razón varianza media de T. chilensis muestreados en el presente estudio.

\begin{tabular}{|c|c|c|c|}
\hline \multicolumn{4}{|c|}{ First group $(\mathrm{n}=90)$ sampled August 01 $1^{\text {st }}, 2011}$. \\
\hline & Total length $(\mathrm{cm})$ & Total weight (gr) & Number of $T$. chilensis \\
\hline Average & 4.05 & 20.57 & 2.74 \\
\hline Minimum & 3.20 & 2.10 & 0.00 \\
\hline Maximum & 4.90 & 36.80 & 20.00 \\
\hline Standard deviation & 0.39 & 6.86 & 3.87 \\
\hline \multicolumn{4}{|c|}{ Variance $/$ mean $=5.45$} \\
\hline \multicolumn{4}{|c|}{ Second group $(n=150)$, sampled August 30 ${ }^{\text {th }}, 2011$. } \\
\hline & Total length $(\mathrm{cm})$ & Total weight (gr) & Number of T. chilensis \\
\hline Average & 3.90 & 15.95 & 1.73 \\
\hline Minimum & 3.10 & 6.79 & 0.00 \\
\hline Maximum & 5.00 & 34.97 & 17.00 \\
\hline Standard desviation & 0.40 & 5.51 & 2.83 \\
\hline
\end{tabular}
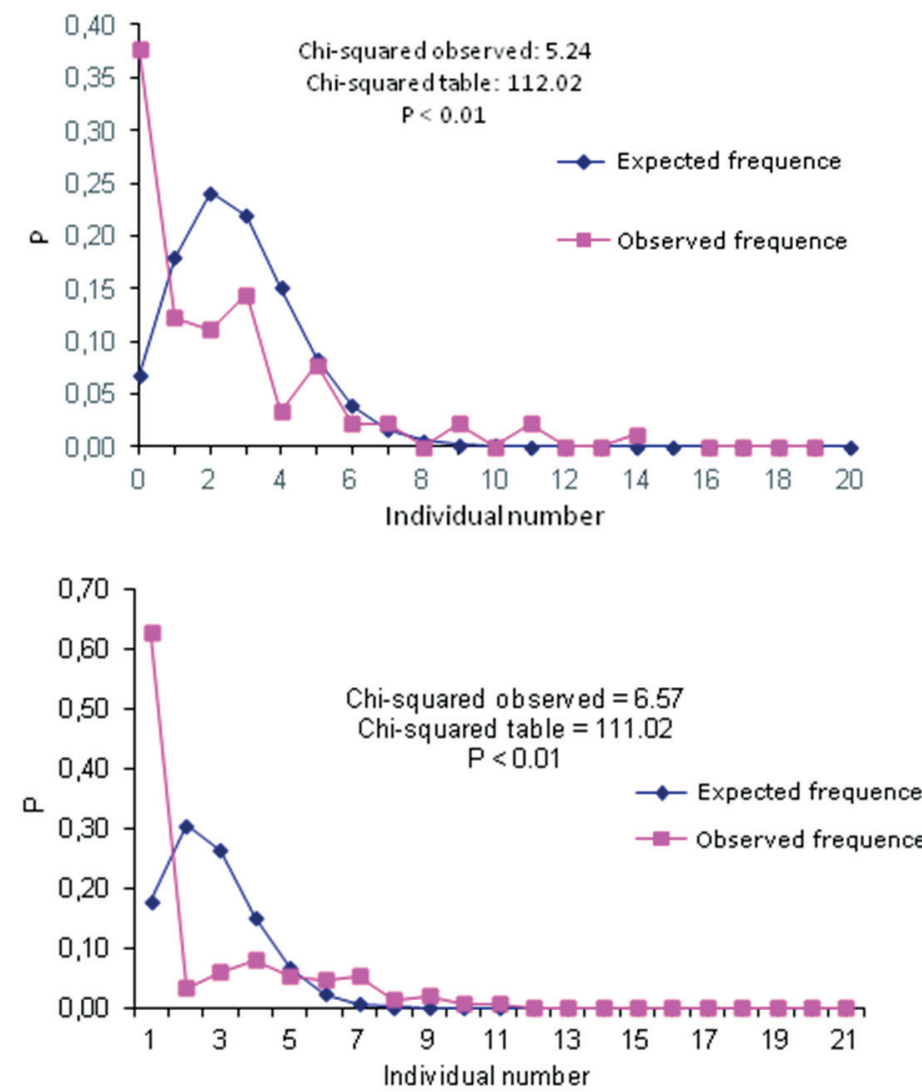

FiguRE 2. Results of negative binomial distribution of $T$. chilensis individuals on $P$. pugnax sampled groups (first group up, $01^{\text {th }}$ August 2012, second group low, $30^{\text {th }}$ August 2012; Y axis: expected frequency; $x$ axis individual numbers).

Figura2. Resultados de la distribución binomial negativa de individuos de T. chilensis en los dos grupos muestreados de P.pugnax (primer grupo 01 de agosto de 2012, segundo grupo 30 de agosto de 2012). 
The presence of this ectocomensal species has been described for Samastacus spinifrons and $P$. pugnax for Chilean inland waters (Rudolph 2002, 2013), and for species of Aegla genus from Central and Southern Argentina and Chile (Damborenea and Cannon 2001). Also, Damborenea \& Cannon (2001), cited to this species for the genus Parastacus in Talcahuano, Chile, unfortunately it was not specified the species of Parastacus. The literature about Temnocephala indicated that this genus has 19 species widespread in neotropical region that are commensals on crustaceans, mollusks, and insects (Damborenea \& Cannon 2001).

The results about aggregate pattern of $T$. chilensis, agree with results for another parasitological studies (PeñaRehbein \& De los Ríos-Escalante 2012), and insects in crop fields (Fernandes et al. 2003). Aggregated pattern is caused by a series of factors as diet, behavior, or immunity, among others. This pattern has consequence for organisms, becauseincrease competition but also allow their reproduction (Poulin 2007). If we considered that many malacostracan inland water species are endemic (Rudolph 2002, 2013), it is probably the existence of marked microendemism at level of parasites and commensals.In this scenario, it would be probably on an evolutive view point that the aggregated pattern would provide an advantage for successful presence of parasites and commensals.

\section{ACKNOWLEDGEMENTS}

The present study was financed by project MECESUP UCT 0804 and the Research Direction of the Catholic University of Temuco and M.I for her valuable comments for improve the manuscript.

\section{BIBLIOGRAPHY}

DAmboreneA, C.\& CANnON L.R.G. 2001. On neotropical Temnocephala (Platyelminthes). Jounal of Natural History, 35(8): 1103-1118.

Fernandes, M.G., BusoliA.C. \& Barbosa, J.C.2003. Distribuição espacial de Alabama argillacea (Hübner) (Lepidoptera: Noctuidae) em algodoeiro.Neotropical Entomology, 32(1): 107-115.

Peña-Rehbein P.\& De los Ríos-Escalante,P. 2012. Use of negative binomial distribution to describe the presence of Anisakis on Thyrsistes atun. Revista Brasileira de Parasitologia Veterinaria, 21(1): 78-80.

Poulin, R. 2007. Evolutionary ecology of parasites:1-332. (Princeton University Press, New Yersey).

Rudolph, E.H. 2002. Sobre la biología del camarón de río Samastacus spinifrons (Phillipii 1882)(Decapoda, Parastacidae). Gayana, 66(2): 147-159.

RudolPh, E.H.2010. Sobre la distribución geográfica de las especies chilenas de Parastacidae (Crustacea, Decapoda, Astacidea). Boletin Chileno de Biodiversidad,3: 32-46.

Rudolph, E.H.2013. Parastacus pugnax (Poeppig, 1835) (Crustacea, Decapoda, Parastacidae): conocimiento biológico, presión extractiva y perspectivas de cultivo. Latin American Journal of Aquatic Research, 41(4): 611632

Zar, J.H. 1999. Biostatistical analysis: 1-663. (Prentice Hall, New Jersey).

Recibido: 29.04 .14

Aceptado: 24.09.14 